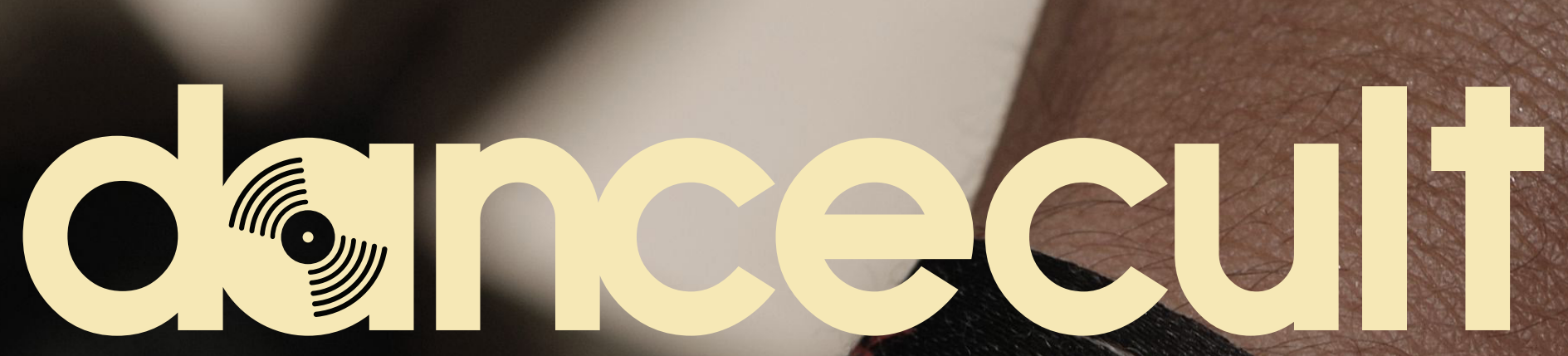

JOURNAL OF ELECTRONIC DANCE MUSIG CULTURE VOLUME 7 NOMBER 1 2015

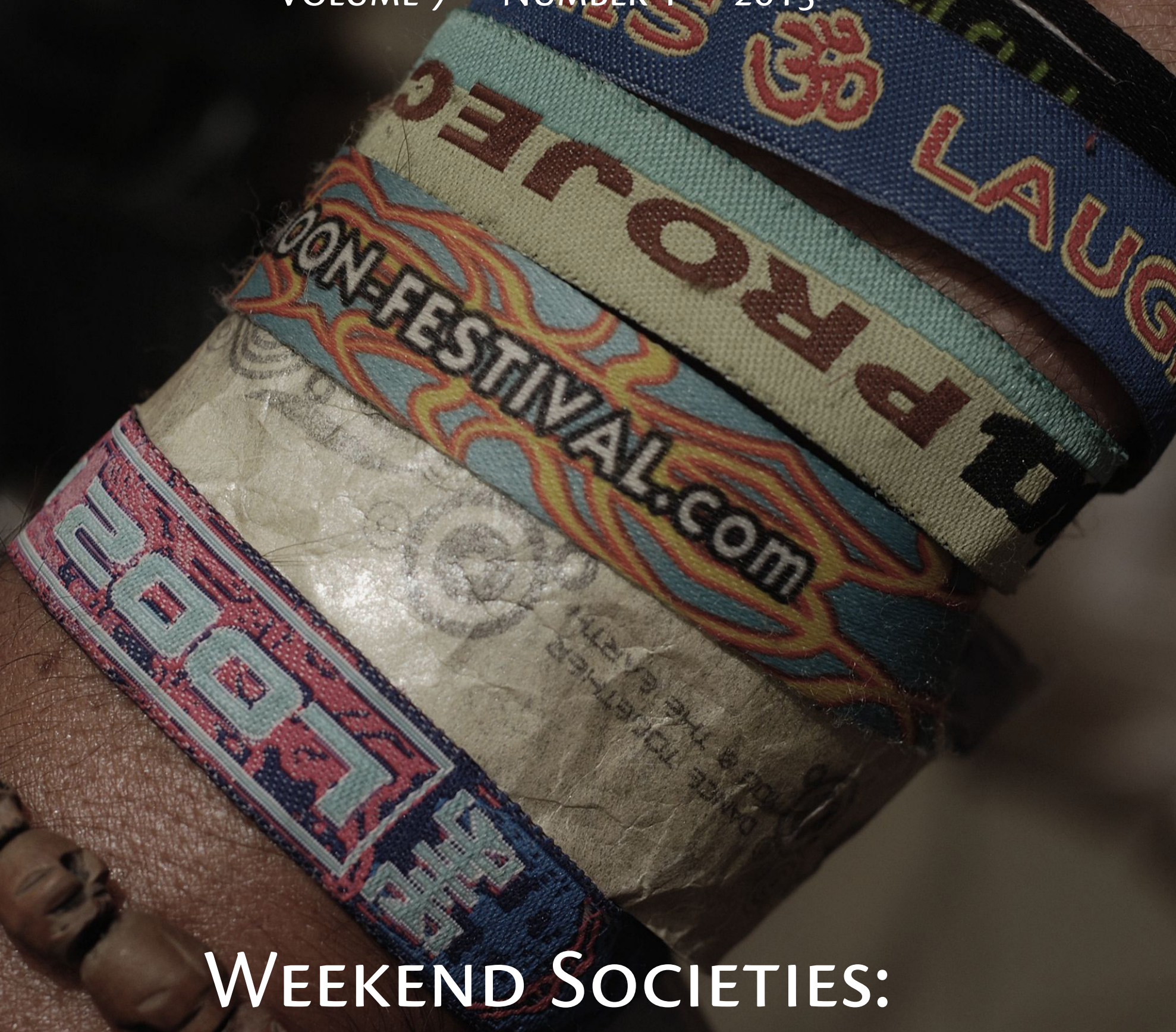

EDM Festivals AND EVEnT-Cultures

EDITED BY GRAHAM ST JOHN 


\section{Dancecult}

JOURNAL OF ELECTRONIC

Dance Music Culture

Issue 7(1) 2015

ISSN 1947-5403

C2015 Dancecult

Published twice yearly at <http://dj.dancecult.net >

EXECUTIVE EDITOR

GRAHAM ST JOHN

(GRIFFITH UNIVERSITY, AU)

FROM THE FLOOR EDITORS

Alice O'Grady

(UNIVERSITY OF LEEDS, UK)

Graham St JOHN

(GRIFFITH UNIVERSITY, AU)

REVIEWS EDITOR

ED MONTANO

(RMIT UNIVERSITY, AU)

FOREIGN LANGUAGES EDITOR

LUIS-ManUel Garcia

(UNIVERSITY OF GRONINGEN, NL)

PRODUCTION EDITOR

BOTOND VITOS (DE)

OPERATIONS DIRECTOR

Ed MONTANo

(RMIT UNIVERSITY, AU)

ART DIRECTOR

BOTOND VITOS (DE)

PUBLICATIONS MANAGER

CARLO NARDI

(RHODES UNIVERSITY, SA)

COPYEDITORS

LUIS-Manuel Garcia

(UNIVERSITY OF GRONINGEN, NL)

JEROME HANSEN (UK)

JONATHAN KARPETZ

(MCGILL UNIVERSITY, CA)

KATRINA LOUGHREY (AU)

Kath O'Donnell (AU)

Magdalena Olszanowski

(CONCORDIA UNIVERSITY, CA)

PRODUCTION ASSISTANTS

Paul Jasen

(Carleton University, CA)

GARTH SHERIDAN

(RMIT UNIVERSITY, AU) 


\section{dancecult \\ JOURNAL OF ELECTRONIC DANCE MUSIC CULTURE \\ ISSN 1947-5403 @2015 Dancecult http://dj.dancecult.net}

VOLUME 7 NUMBer 12015

Introduction to Weekend Societies: EDM Festivals and Event-Cultures $\ldots \ldots \ldots \ldots \ldots \ldots \ldots$

GRAHAM ST JOHN

\section{FEATURE ARTICLES}

Searching for a Cultural Home: Asian American Youth in the EDM Festival Scene . . . . . . . . . . 15

JUDY SOOJIN PARK

Boutiquing at the Raindance Campout: Relational Aesthetics as Festival Technology . . . . . . . . 35

BRYAN SCHMIDT

Harm Reduction or Psychedelic Support? Caring for Drug-Related Crises at Transformational Festivals. . 55

DEIRDRE RUANE

Dancing Outdoors:

DiY Ethics and Democratised Practices of Well-being on the UK Alternative Festival Circuit . . . . . . 76

ALICE O'GRADY

Folk Music and Commercialization in Danubian Trances and Boheme . . . . . . . . . . . . . . 97

BARBARA ROSE LANGE

\section{TRANSPOSITIONS}

Free Parties and Teknivals: Gift-Exchange and Participation on the Margins of the Market and the State. . .116 anne Petiau (trans. Luis-Manuel Garcia)

\section{FROM THE FLOOR - ONLINE}

Dead by Dawn, 1995

DJ BALLI

Strobe Light Salvation

MichaEL ARTY GHANNOUM

\section{REVIEWS}

\section{Books}

Goa: 20 Years of Psychedelic Trance (Tom Rom and Pascal Querner). . . . . . . . . . . . . . . . . . . 129 JOSHUA SCHMIDT

Danger Mouse's The Grey Album (33 1/3 Series) (Charles Fairchild) . . . . . . . . . . . . . . . . . 132 IAN ROGERS

The Globalization of Musics in Transit: Music Migration and Tourism

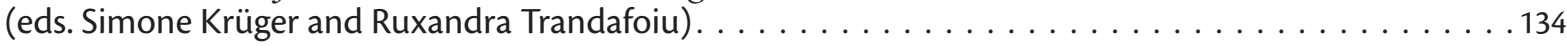
GARTH SHERIDAN

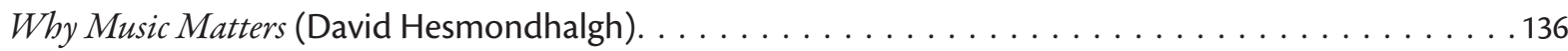
Kat NeLLIGAN

Music, Style, and Aging: Growing Old Disgracefully? (Andy Bennett)

Ageing and Youth Cultures: Music, Style and Identity (eds. Andy Bennett and Paul Hodkinson) . . . . . . 139 LIZ GIUFFRE 


\title{
INTRODUCtion to WeEkEND SOCIETIES: EDM Festivals and EVEnT-Cultures
}

\author{
EDITORS' INTRODUCTION \\ GRAHAM ST JOHN \\ GRIFFITH UNIVERSITY (AUSTRALIA)
}

$\longrightarrow$

GRAHAM ST JOHN is an anthropologist specialising in dance movements, event-cultures and entheogens. He is author of the forthcoming Mystery School in Hyperspace: A Cultural History of DMT (Evolver, 2015), the monographs Global Tribe: Technology, Spirituality and Psytrance (Equinox, 2012) and Technomad: Global Raving Countercultures (Equinox, 2009), in addition to five edited collections, including the forthcoming Weekend Societies: Dance Festivals and Event-Cultures (Bloomsbury 2016). Graham is founding Executive Editor of Dancecult and is Adjunct Research Fellow at Griffith Centre for Cultural Research, Griffith University. His website is < www.edgecentral.net $>$.

Researchers across the spectrum of social and cultural disciplines have, in recent times, sought to bring understanding to a growing cultural pattern where festivals have become integral to tourism and regional cultural economies and to the performance of identity and lifestyle. While electronic dance music $\left(\mathrm{EDM}^{1}\right)$ cultures are implicated in the "festivalisation of culture" (Bennett, Taylor and Woodward 2014), they have lent their own unique sensibility to the pattern over the past two decades, at the crossroads of diverse local and global influences. When I say unique, I mean that electronic dance music culture possesses distinct festal roots, in the club, the rave, the party. Beneath its diverse variations, it is an event-culture. But to refer to EDM festivalisation is to acknowledge the variegated ways in which the local events and native cultures of dance music have evolved (and some might even argue devolved) into larger scale mediated cultural events and global festivals.

So far as dance cultural studies is concerned, this is relatively fresh terrain, despite the fact that EDM cultural events and their event-cultures proliferate and diversify rapidly. The local/global socio-cultural complexity of dance festivals demands conceptual frameworks capable of rendering these practices amenable to understanding-frameworks that will inevitably evolve from sustained ethnographic and multi-methods research. This is the kind of research that, for instance, led Chalcraft and Magaudda (2013), by way of a comparison of Sònar and WOMAD, to coin the phrase "festivalscape", a concept inspired by Appadurai's

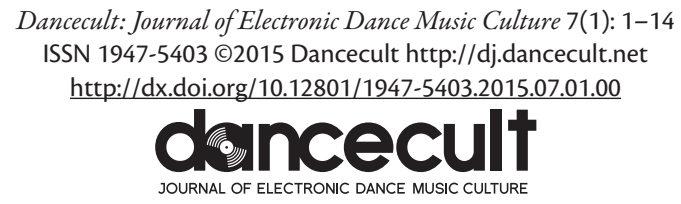


(1990) variety of “-scapes"-ethnoscapes, mediascapes, technoscapes, financescapes and ideoscapes - each comprising unique sets of "flows" that intersect with others at the shifting local-global disjunctures of modernity. All such "scapes" intersect in the festival, a topos greater than its components.

Festivalscapes are a set of cultural, material and social flows, at both local and global levels, both concrete and imagined, both deliberate and unintended, which emerge and are established during a specific festival. In this sense, festivals can be seen and analysed as terrains where different cultural, aesthetic and political patterns and values temporarily converge and clash, constantly creating, stabilizing and redefining the setting of festival interaction, and in so doing stressing the problems raised by the multiple articulation of global cultural flows, local life and spatiality (Chalcraft and Magaudda 2013: 174).

If music festivals, themselves diverse popular cultural phenomena (see McKay 2015), offer privileged perspectives on the "local globalities" of late modernity (Chalcraft and Magaudda 2013), EDM festivalscapes are unique lenses on the diversity of such intersections, albeit substantively under-researched. While there have been a variety of approaches to dance cultural industries, including cultural histories of disco (Lawrence 2003) and transnational house club culture (Rietveld 1998), studies of regional (Buckland 2002; Anderson 2009) or "hypermobile" (D’Andrea 2007) scenes, there has been no sustained study of EDM festivalisation, including research that could observe the evolution of a cultural industry through the fates of individual cultural events.

EDM culture lies at the crossroads of local dance event origins and global industry imperatives. This themed issue of Dancecult offers a selective introduction to this development in advance of an edited volume, Weekend Societies, forthcoming with Bloomsbury. Feature articles in this edition of Dancecult will be republished in that interdisciplinary volume which will offer, by way of its greater range of contributions, a more comprehensive statement on the emergence and development of EDM festivals and their event-cultures. This edition then offers something of a teaser to that volume, like a flyer to the main event coming soon.

From massive anarcho-libertarian raves sprouting around the London orbital at the turn of the 1990s, to dance empires responsible for cross-genre ("EDM"), multi-city, transnational mega-raves, dance music festivals have flourished worldwide over the last twenty-five years. They have become platforms for a variety of arts, lifestyles, industries, policies and indeed event-cultures, whether free-party teknivals proliferating across Europe since the mid-1990s; colossal attractions like Belgium's Tomorrowland, a "festival world" enabled by new forms of mediatisation (Holt 2015) and attracting more than four hundred thousand people over two weekends in July of 2014; "transformational festivals" like Southern California's Lightning in a Bottle; or digital arts and new media showcases like Montreal's MUTEK and Barcelona’s Sónar Festival, the event most instrumental "in legitimizing electronic music as an artform" (Chalcraft and Magaudda 2013: 187). 
The proliferation of dance festivals is an echo of the profusion of dance cultures and their night and day worlds. While weekend societies are exemplary event-centred cultures that provide their memberships with identification and recognition independent from traditional sources (e.g. ethnicity, faith, class), eventised movements are diverse in their organisation, intention and populations. From ethically-charged events with commitments to local regions and indigenous communities to subsidiaries of entertainment conglomerates touring multiple nations annually, EDM festivals are expressions of "freedoms" that are revolutionary and recreational. Co-created "do-ocracies" inspired by Burning Man or corporate sponsored bureaucracies in the mould of Electric Daisy Carnival, churches of genre or ecumenical free-for-alls, DJ-driven or fusional by design, offering sustainable solutions or orgies of excess, with habitués worshipping brand-name DJs or showing support for independent sound systems, diversity is evident across management styles, mediatisation strategies, performance legacies and modes of participation.

From Detroit's Movement Electronic Music Festival to Portugal's Boom Festival, dance music festivals have become stages for the performance of transnational meta-cultural aesthetics (e.g. techno, dub, psychedelic) and their potential synthesis. Characterised by meteoric rises, like Insomnia Events' Electric Daisy Carnival (EDC), and tragic demises, like Berlin's Love Parade (Nye and Hitzler 2011), these events have become major cultural and tourism industry hubs. With stakeholders and ticketholders carrying disparate motives, styles and expectations they are contested sites. As cultural flashpoints, dance festivals continually incite fledgling operations under variable missions-reclaiming tradition, maintaining independence, selling culture, reducing harm, evolving consciousness-all transpiring at the verges of the dance floor.

\section{Dance Event-Cultures and Festivalisation}

The history of EDM culture is in large part a story of the emergence of dance events and the cultures that have sustained them. It is a story of interrelated eventised dance movements that in many cases have evolved from localised cultural events (i.e. raves) to global cultural events (international, global festivals). Between these ends of the spectrum, the story typically involves the formation of event-cultures; e.g. acid house, rave, techno, psytrance, dub cultures and their diasporic movements whose populations have as their common purpose the dance event. Such are festal enclaves beyond which their "cultures" may have little prestige or currency. It is a story that holds a different narrative according to the eventculture in question, a narrative that may change in tone depending on whom among the variety of stakeholders one dialogues with. While there have been diverse event-centred dance cultures emergent in this development, here I reflect upon two distinct forms. One is the free-party tekno sound system culture that flourished in France, Italy and elsewhere in Europe from the mid-1990s, which was inspired by Spiral Tribe and other sound systems formed from collaborations between travellers and ravers, a development that saw the formation of teknivals (St John 2009: ch 2). The other is psyculture, which emerged in the wake of Goatrance and which caused the birth of Portugal's Boom Festival among a 
now crowded calendar of psychedelic trance festivals in Europe and worldwide (Rom and Querner 2011; St John 2014a). Despite the differences between these festal cultures, the variations in ethics, technics and sensory aesthetics, they share utopian sensibilities shaped by responses to lifeworld circumstances, not least of all state regulation and corporatisation of dance music culture, and indeed the mainstreaming of "EDM". Across these eventcentred movements we find fiercely independent music and event-industries reliant on the $\mathrm{re} /$ production of the festival, a space of gift-exchange and alternative commercial economies that are most consistent in "free" (or by donation) events.

As Anne Petiau states in her contribution to this edition, "Free Parties and Teknivals: Gift-Exchange and Participation on the Margins of the Market and the State" (translated by Dancecult's Foreign Languages Editor Luis Manuel-Garcia from the French original), "in these alternative festive practices, one can recognise the means by which individuals constantly re-establish social ties relevant to a system of gift-exchange, whether outside the systems of market and state or in their interstices". Petiau explores the status of the French teknival as gift, a reciprocal logic distributed throughout the worldwide teknival movement where event-goers are encouraged to contribute to and effectively co-create events. The ethos of participation or "no spectators" can also be found at the root of psychedelic trance events in Goa, and in every region of its emergence worldwide. But it is an ethos that is also challenged in each region, as small-scale events burgeon into festivals, as markets grow and fan-bases develop, as DJ cultures become celebrity cultures, as cottage industries become cultural industries.

Original scenes are challenged as artists become inflated into headphone-wearing icons occupying stages that grow higher and more elaborate, and where the gulf between the elevated artist and a vast sea of dancers-including those watching live-feeds at locations inside the venue or on the other side of the planet-grows wider. Maintaining an original PLUR ethos becomes a dubitable motivation for massive up-scaled festivals like Insomniac's Electric Daisy Carnival. If EDC, mounted in numerous locations annually across the US and abroad, amounts to a "religious experience" for participants—as observed by DJ Tiesto in Under the Electric Sky (Cutforth and Lipsitz 2014), the documentary film for the 2013 Las Vegas EDC-one could speculate on the apparatus responsible for eliciting transcendence on a scale that attracted three hundred and fifty thousand people to the event at the Las Vegas Motor Speedway that year. In the film, one designer offers this insight: "people are coming here to be inspired. If you go back to the purpose of cathedrals and what people were going for, it was to feel small and spiritually alive". Making people feel small amid the spectacle is lucrative for Insomniac founder Pasquale Rotella who, at one point in the film, casts a commanding gaze across the EDC spectacle aboard a VIP float. Strategic eventaggrandizement of this nature appears to have become indispensable to festival marketing since the Tomorrowland 2011 aftermovie (Tomorrowland 2011). In Fabian Holt's analysis, that film converts the cultural event into a cinematic experience. 
It offers an emotional journey through the festival with footage from locations, stages, and crowd situations that give a sense of a euphoric festival experience. More than simply a sequence of episodes, the video is edited to build emotional momentum and convey a sense of physical arrival at the festival site and to show how the festival evolves from day to night. The cinematic flow is filled with symbolic gestures, such as smiles and kisses to the camera, party photograph posing, and pretty people, all of which are typical elements in corporate-style marketing videos-but with larger euphoric crowds and DJ superstars (Holt 2015).

As a mediated effort to capture the immediacy of an event, could the cinematic experience augment an event-culture, in this case that which is enlivened by the sounds of Progressive House? Such triggers an avalanche of questions concerning the role of new mediatisation practices in EDM cultural events, notably the deregulation of broadcasting that has permitted event-organisations to distribute video by way of YouTube and social media. What might cultural events and beyond that, event-cultures, look like in these "new configurations of time, space and capital" (Holt 2015)? What are the dimensions of the "event" in a world of infinitely remediated live-feeds, and where aftermovies are "digital folkloric texts that everyone shares" (Holt 2015). And "is it possible to base a culture", as Simon Reynolds asked nearly two decades ago, "around sensations rather than truths, fascination rather than meaning, jouissance rather than plaisir?" (1997: 109). For event marketing strategists, the answer is probably "yes", if by "culture" one means a brand to which event-goers are loyal.

To observe the festivalisation of dance culture is in some ways to observe the career of the liminal experience that has been emically recognised as the vibe-the socio-sonic experiential currency valued across dance scenes. Many researchers have recognised that the sociality of the much vaunted vibe approximates the undifferentiated sensation of "spontaneous communitas" (Turner 1969). For experients, this is a social juncture in which one participates wholly_not a spectator. In the "discommunitas" of EDM, such participation ultimately involves the dissolution of subjectivity in which one becomes other to one's self. In all the regions of its development, EDM event managers typically recall that ur-moment when "it all made sense", that protean transformative juncture that afforded the inspiration to mount events that attempt to recreate the primal rave, augmented by sensory technologies and event design. Among the chief aspects of communitas is its capacity to unify strangers, each of whom are wholly attending, including those with disparate backgrounds, aesthetics and ethnicities. In the worldwide localities, or global localities, of its emergence-usually within metropolitan centres, but also in expatriate and experimental enclaves such as Goa in the late 1980s, Black Rock City (or Burning Man, see Jones 2011; St John 2014b), or perhaps Germany's Fusion Festival - the non-local community of the EDM festival is stamped with cosmopolitan relationships (see also Lalioti 2013). While art festivals are known to explicitly privilege the encounter, exchange and dialogue with the Other (Chalcraft, Delanty and Sassatelli 2014), the dance festival is primarily dedicated to optimising the conditions for the othering of the self. There have been few attempts to critically address such relationships within EDM cultural events and their event-cultures, 
which have proclaimed utopic sensibilities inscribed, for example, in the mythos of PLUR (Peace, Love, Unity, Respect), or the psychedelic dissolution of self-other boundaries. An exception is Judy Soojin Park's opening article in this edition "Searching for a Cultural Home: Asian American Youth in the EDM Festival Scene", which addresses racial stereotyping within scenes that have typically promoted egalitarianism. Park's study of Insomniac Events in Southern California demonstrates how Asian American participants leverage "belonging" in a middle-class white dominated scene by way of the imagined other of "urban hip-hop blackness". By focusing on the negotiations of race and class by nonwhite participants' in EDM festival scenes, Park's work is representative of a neglected research direction within EDM cultural studies.

Dance festivals hold varying commitments to the varieties of cosmopolitanism identified by Chalcraft, Delanty and Sassatelli (2014: 111) —including the relativisation of one's own identity, positive recognition of the other, mutual evaluation of cultures and a shared normative culture, which involves self-Other relations that are "mediated through an orientation towards world consciousness." With regard to the latter, Portugal's Boom Festival commands attention as a vehicle for "planetary consciousness", a hallmark expression in the psycultural diaspora, as evident in total solar eclipse festivals (St John 2013). While these festivals are characterised by a "global" consciousness, as reflected in cultural programming, ecological sustainability programs, artist nationalities and attendance by international "travellers", they are nevertheless mounted within national borders where host cultures shape event management, promotion, programming and participant experience. But while host nations curate events, there is ambivalence expressed within psyculture towards national identity. On the one hand, one's nationality is valued. In Alchemy of Spirit, the documentary produced on Boom 2012 (DROID i.d. 2013), the many participants vox-popped at the film's beginning are asked to state their country of origin. Many nations are identified, and Boom revels in the multitude of national passport-holders represented at the event. For example, the front page of the Boom 2014 newspaper The Dharma Dragon celebrated the presence of ticket-holders from a record one hundred and fifty two nations at that event. National identity is performed on site, including by way of national flag displays by individual dancers. And yet such displays are not without controversy. In 2014, also by way of The Dharma Dragon, Boom issued an edict to the effect that there should be no displays of national flags inside the main dance floor: the Dance Temple. It is an observance consistent with that venue's stature as a sacred site, a global destination for transcendence-seeking pilgrims, a "mothership" in which one becomes temporarily abducted from standard identifiers (like nationality).

\section{Transformational Festivals}

Given that three of the articles in this edition of Dancecult address the subject, discussion of the phenomenon of "transformational festivals" is pertinent here. I have long been cognisant that festivals, especially those across the alternative spectrum of events, are transformational. In fact, this is among my chief motivations for researching such events, that they permit entrants to become liminars (literally: threshold dwellers) while occupying the demarcated 
time-space framework of the event. As festal citizens, participants are afforded passage into a transitional world possessing liminal conditions and carnivalesque logics (or illogics) to which inhabitants are compelled to surrender. The mood prevailing is, as Victor Turner knew, not inconsistent with a rite of passage, a structured ritual which possesses the power to transform an individual's status, identity and life; only, the liminality of the modern festival holds heterogenous, elective and hyper-mediated characteristics. Raves and other dance events in the EDM spectrum have embraced the transitional logic of the rite of passage, with ravers liminars par excellence. Whether revelatory practitioner accounts, or scholarly treatises, or those combining these approaches, EDMC literature offers testimony to the power of rave, techno, house, trance, etc, to transform participants, with experients typically claiming that events have changed lives, occasioning the formation of associations, causing re-evaluations of lifestyle, consumer and relationship patterns and the fashioning of more and more raves. In those events where the economic and aesthetic contribution of participants is encouraged, the cultures endogenous to these events are stamped with the imprimatur of transformative potentiality.

Today, an event model appears to have harnessed and bottled this logic. "Transformational festivals", in which electronic music often predominates (although not exclusively), like Lightning in a Bottle (California), Symbiosis (Nevada), Lucidity (Southern California), The Oracle Gatherings (Seattle), Beloved (Oregon), Shambhala (British Columbia), Sunrise Celebration (UK), Envision (Costa Rica), Boom (Portugal), ${ }^{2}$ among many others, are downstream from the confluence of various countercultural event models, including: West Coast North American festival culture, notably Burning Man; UK Free Festivals in the Traveller tradition; and Goa Trance/psytrance and psychedelic electronica. We could trace several interwoven movements influencing these event models: progressive consciousness evolutionary agendas that have typically been associated with the New Age movement; sensory technologies and their purposeful-"shamanic" or "gnostic"-application, as documented, for instance, in the film Electronic Awakening (Johner 2011); healing arts and the human potential movement; egalitarianism, civic engagement and direct democracy (Turner 2014); the back to the land movement, sustainability practices and permaculture; the visionary arts movement and entheogens; embracing and appropriation of indigeneity (ritual and symbolism).

Shedding light on transformational festivals, Bryan Schmidt in his article, "Boutiquing at the Raindance Campout: Relational Aesthetics as Festival Technology", states that these events include "an ecstatic core ritual provided through electronic dance music; visionary art, performance, art installations and live art; a workshop curriculum covering a spectrum of New Paradigm subjects; the creation and honoring of sacred space; ceremony and ritual; a social economy of artisans and vendors (or, alternative gift economy); a natural, outdoor setting to honor the Earth; and a multiple (typically 3-7) day duration". These are the paraphrased observations of Jeet-Kei Leung, a documentary film-maker from Vancouver who popularised (and capitalised) the phrase "Transformational Festival" in a 2010 TEDx talk and subsequently produced a four-part documentary webseries The Bloom (Leung and Chan 2014). 
These events, then, are programmatically transformational. That is, we can identify within their precincts the interwoven agendas of personal growth and global consciousness that are a legacy of the transpersonal counterculture. Reliant on a transformational architectonic, that these event-industries are commercial operations catering for a select middle-class event-going market is inscribed in the idea of the "boutique" festival, a term sometimes used, as with Schmidt, interchangeably with "transformational festival". "Boutique festivals", which have evolved rapidly in the UK in the last decade, involve substantial programming diversity, in which EDM can be a minor element, although typically substantive, as in BoomTown Fair. These are participatory arts festivals, involving "ethical living", possessing no commercial sponsorship, offering diverse dance music genres and lifestyle workshops and often "upmarket amenities" (including glamour camping, or "glamping", in yurts, podpads and tipis). Within an intensely competitive festival market, event survival and growth relies on events becoming strategically distinguished from those that do not offer countercultural authentica in their experiential design. Critical to this festival-based authenticity is the degree to which events are removed from those where the "main stage" and lineups predominate proceedings (and promotions), and where festivalgoers are empowered to be co-creators in event production, a collaboration that takes diverse forms: from programming input, to costuming and theatrical performance, to simply dancing.

By contrast to the hypermediated mainfloor mentality sponsored by Smirnoff, the boutique festival is presented as "the informed consumer's choice; one who appreciates, and has the means to adhere to, a green and ethical lifestyle as part of leading a sustainable and responsible existence". As Johansson and Toraldo (2015: 9) further suggest, "the implication is that by choosing the boutique experience, the consumer also performs an active choice of separation from the mainstream", a process these authors imply is illusory. The "experience design" of these weekend societies provides the opportunity for "temporary countercultural identity performances" (Johansson and Toraldo 2015: 11), a position echoing long held assumptions about the carnival as safety valve. While the idealisation of consumer participation is integral to these festivals, whether "co-creativity" is an expression of the creative agency of individuals or "exploitation in the form of free labour through the expropriation of knowledge, creativity and communication" (Johansson and Toraldo 2015: 4 ), is open to interpretation. We are not far removed, it seems, from what marketing and consumption researchers refer to as the "co-creation of value" in the fashioning of brands (Pongsakornrungsilp and Schroeder 2011). The enterprising consumer may be the ideal event-goer within this type of event that embraces a philosophy of participation consistent with the mythos of the autonomous individual whose exercise of choice paves the way to prosperity, and/or democracy. Whether events offer micro-models of neoliberalism (or democracy), encouragement of participant agency straddling the consumer/producer divide appears to be the hallmark strategy of the transformational festival, events that routinely cite the ethos of Burning Man, the annual Nevada countercultural event also known as Black Rock City, as inspirational. According to Chen (2012) the "inclusive community logic" of Burning Man transforms participants into prosumerists (participants who 
produce and consume), a simultaneity also recognised as integral to consumer tribalism (see Cova, Kozinets and Shankar 2007). Burning Man demonstrates that prosumerism can be harnessed to ends other than profit margins, a circumstance that has provided motivation for immersive art festivals worldwide in a variety of ways and with varying degrees of success. Turning to Bourriaud's "relational aesthetics" to expose in exuberant ethnographic detail the relational and open-ended social artifice of the Californian Raindance Campout, Schmidt also begins unpacking some of the internal conflicts native to the operation of such events, including the privileged status of participants and the fraught terrain of cultural appropriation.

That such festivals are dynamic experimental sites where the shaping influence of conflicting discourse and practice and policies and behaviour, are negotiated in-situ, is confirmed in Deirdre Ruane's article, "Harm Reduction or Psychedelic Support? Caring for Drug-Related Crises at Transformational Festivals". Ruane's multi-sited ethnography of voluntary care-provision organisations at Boom, Burning Man and Secret Garden Party illustrates how these events are dynamic proving-grounds for competing paradigms of drugs, drug users and the self. This is a field warranting far more attention from researchers and Ruane offers a sound beginning.

While Burning Man has inspired UK festivals like Secret Garden Party and BoomTown Fair, such events appear to cherrypick from the principles of Black Rock City, effectively "remodelling the 'No Spectators' ethos to fit within their own economic framework" (Robinson 2015: 173). Still, this should be kept in perspective. While these events are not prestigious "free-party" universes obligating forms of gift-exchange and event coproduction (as in the logic of the teknival), they do not, at the same time, offer "Electric Sky Package" tickets (at \$5,000) with access to private front-row tables with prime stage views on the "VIP Cabana Deck", as sold by Insomniac Events for EDC New York 2015. While the capitalist cultural logic behind this strategy appears to be about as removed from "free", "inclusive" and "authentic" dispositions as possible, resistance to such developments continues to prompt alternatives within the EDM culture industry. Indeed, the embrace of participative arts and popular immersive theatricality offers a face-palm to the star/audience, producer/consumer divisions magnified beyond measure at EDC. With that said, as Under the Electric Sky demonstrates, ravers remain eternal participants by way of the shared dance ekstasis-eternalised further through hyper-social mediations of "eternity" on Facebook. But it will be critical longitudinal studies of dance and electronic arts festivalscapes and their cultural industries, research of the kind that prizes open the motivations, imperatives and strategies of transnational dance entertainment empires, that will determine more precisely what it is that event-goers are participating in. Such studies would doubtlessly uncover a diversity of experimental co/production practices, like that found, for instance at the S.U.N. Summer Gathering in Hungary whose ticketing strategy is an innovation in the democratisation of festival space. For its third annual event, S.U.N. implemented a strategy where ticketholders are provided the opportunity to shape the direction and content of the festival as "members" with rights to vote for major acts and land development projects. ${ }^{3}$ 
Among the key recurring features of these recurrent events is that they are visited by participants who often travel significant distances (regionally and internationally). Travel to and altered experiences within rural spaces are among the features of these events appealing to their populace, typically urban-dwelling participants temporarily vacating. The affective dimensions of festive rurality are among the chief characteristics of alternative EDM festivals in the UK explored by Alice O'Grady in her article in this edition, "Dancing Outdoors: DiY Ethics and Democratised Practices of Well-being on the UK Alternative Festival Circuit". While holding kinship with transformational festivals, these events are said to possess distinct roots in the UK free party movement arising from the convergence of Travellers and DiY sound systems. O'Grady is concerned with how these events, which also borrow from traditions like "garden parties, English fetes, camping trips, wilderness adventures", prioritise the rural idyll and foster authenticity by way of temporary relocation into the countryside. While it is unstated in O'Grady's analysis, I suspect that part of the appeal of these events, their capacity for enhancing "well-being", is that they are not just experimental spaces, but familiar spaces of experimentation.

And yet festivals rarely survive without innovation, which in countries with cluttered events calendars like the UK, the US, Germany and Australia, requires strategic efforts to gain the favour of, and build support from, the event-going public. Like other cultural goods and services, the value of the festival emerges not only in its consumption, but in "the anticipation of a desired experience" (Johansson and Toraldo 2015: 5). And perhaps nothing builds excitement more than the promise of surprise (i.e. that which is alternative to what is available elsewhere). But while novelty is implicit to the event design of EDM festivals, a circumstance ensuring event-management will continue to innovate, events also possess a drawing power that relies on their ability to return eventgoers to a familiar place. We might understand this by way of the highly anticipated "little death" of the ecstatic dance state, the entranced condition, in which the experient is permitted to go out of their mind in the company of others, friends and strangers alike, a circumstance augmented through intention and experience design. The popular desire for this condition might be stated to be the desire to be without desire, even however fleetingly. But understanding of the "little death" of the festival cannot arrive by way of discursive analyses. Building anticipation for novelty is critical within the EDM culture industry, where mediators, none less than DJ/producers and label promoters (some of whom operate their own festivals or manage event sound-stages), play an important role in fashioning innovative style, genre iterations, tempo changes, typically formulated through the fusion of existing aesthetic elements, by which an original experience is promised. But the quest for originality in the laboratory of dance is countermanded by the desire for the familiar, the return to origins. This festal tension echoes the logic of Csikszentmihalyi's (1990) "flow" state. Here, an experience is characterised as "flowing" where the artifice experienced (i.e. sport, music) is novel, and yet not too novel. The tension is especially 
evident in scenes that display remarkable resilience, like psytrance (see O'Grady 2015), whose participants will return time and again to a "vibe" that is furnished by aesthetic conventions that are both timeless (e.g. the 16th note) and challenging (e.g. new styles like "hitech"). Across dance music scenes the "vibe" represents a curious balancing act of novelty and familiarity, innovation and authenticity, change and stasis, the tensions between which appears to illuminate that experience most endearing to event nativesthe familiar otherness of ekstasis. This logic is recognised by Thomas Turino who offers insight on the role of challenges in the optimizing of the musical experience sought by those who will return time and again to re-enter the flow.

These are states associated with activities that must include the proper balance between inherent challenges and the skill level of the actor. If the challenges are too low, the activity becomes boring and the mind wanders; if the challenges are too high, the activity leads to frustration and the actor cannot engage fully. When the balance is just right, it enhances concentration and that sense of being at one with the activity and perhaps the other people involved (Turino 2008: 4).

In EDM scenes, music producers, event organisers and dance floor occupants attempt to maintain this harmony, the balancing of which in recurrent and reversioned events offers insight on the nature of "progressive" sensibilities (for psytrance, see St John 2012: 214-15). While this familiar difference empowers participants to enter experimental and transformative states of selfhood, finding the tension-line amid shifting aesthetics grows increasingly difficult as EDM cultural events expand to host disparate event-tribes inside their sprawling precincts, such as might be found at Germany's Fusion Festival. As events grow in scale to accommodate more music styles, performance arts and other options across vast sites, some of them visited by a hundred thousand for a night, others camped in by a few hundred over a week, their liminal domains grow complex. If originary cultural events represent an arguably simplistic case of liminality, larger scale events are hyperliminal contexts, which in the case of Boom, for example, illustrates the propensity for energy sustainability and expenditure sought in equal measure by convergent populations ( $\mathrm{St}$ John 2014c). Other events falling under the transformational rubric tend to offer multiple means for transition by permitting event publics the ability to perform variable identities that emerge on a status spectrum between consumer (the entertained) and producer (the artist), the complex liminal conditions of which warrants further consideration in the emergent field of EDM festival studies.

This returns me to the logic of the transformational festival, and not to mention many other events consciously investing in a transformational logic. Such events rely upon the development of cultural industries dedicated to augmenting the conditions of participant liminality through the optimising of event experience design, sensory technologies and prosumer arts. This event-liminalisation raises questions about the supposed efficacy of these recurrent events, inquiries that will benefit from sustained and longitudinal studies of festivals. One might inquire, for example, as to whether these events facilitate 
transformations in personal, social and cultural conditions according to the passage rite model in which these festivals typically invest, or are they more akin to transitional worlds, parallel cultural universes and liminal mini-states to which event-goers and raving liminars repeatedly return? Does event attendance afford passage and recognition outside of the event, or does event experience, relationships and prestige hold currency only within the eventised culture itself?

As earlier mentioned, while this edition has several chapters addressing the transformational festival, the forthcoming Bloomsbury volume on EDM festivals aims to expand considerably upon this rather narrowband analysis of EDM festivalisation.

This edition of Dancecult includes several other contributions. There is a feature article by Barbara Rose Lange, whose "Folk Music and Commercialization in Danubian Trances and Boheme" explores debates in Hungary in response to Deep Forest's 1995 album Bobeme and Károly Cserepes's 2003 album Danubian Trances: mikroworld-ambient. There are also included two From the Floor pieces. The first is a further chapter installment from Riccardo Balli's book Apocalypso Disco: La Rave-o-luzione della Post Techno. Translated from the Italian by Balli himself, the text offers a valuable first-hand account of London's formative Dead by Dawn parties of the mid-1990s. The second, "Strobe Light Salvation", by Montreal-based writer Michael Arty Ghannoum, offers an eye-opening entry into the club and represents the style of experiential narrative that this section of the journal was designed for. The issue also includes five book review articles, diligently brought to you by Ed Montano.

Many thanks to all our copyeditors, including two new team members: Jonathan Karpetz and Magdalena Olszanowski (joining Kath O’Donnell for this issue). And thanks again to Botond Vitos (wearing hats as Production Editor and Art Director) for bringing this issue home.

\section{NOTES}

1 While this introduction and the articles in this edition of Dancecult refer to "EDM festivals", this should not be confused with the cross-genrefied market designation "EDM" which has been mainstreamed by way of event organisations like Electric Daisy Carnival. In this introduction, I use "dance festivals" interchangeably with "EDM festivals".

2 While there are proposed to be ninety "transformational festivals", there is debate and disagreement about which events meet Jeet-Kei Leung's criteria set out at $<\underline{\text { http://thebloomseries.com/guidelines-for-inclusion-transformational-festivals-map }>}$ (accessed 13 May 2015).

3 < http://solarunitednatives.org > (accessed 15 May 2015). 


\section{REFERENCES}

Anderson, Tammy L. 2009. Rave Culture: The Alteration and Decline of a Philadelphia Music Scene. Philadelphia, PA: Temple University Press.

Appadurai, Arjun. 1990. "Disjuncture and Difference in the Global Cultural Economy”. Theory, Culture \& Society 7(2): 295-310. < http://dx.doi.org/10.1177/026327690007002017>.

Bennett, Andy, Jodie Taylor and Ian Woodward, eds. 2014. The Festivalisation of Culture. Aldershot: Ashgate.

Buckland, Fiona. 2002. Impossible Dance: Club Culture and Queer World-Making. Middletown: Wesleyan University Press.

Chalcraft, Jasper, Gerard Delanty and Monica Sassatelli. 2014. "Varieties of Cosmopolitanism in Art Festivals". In The Festivalisation of Culture, eds. Andy Bennett, Jodie Taylor and Ian Woodward, 109-130. Aldershot: Ashgate.

Chalcraft, Jasper and Paolo Magaudda. 2013. “'Space is the Place': The Global Localities of the Sònar and WOMAD Music Festivals". In Festivals and the Cultural Public Sphere, eds. Gerard Delanty, Liana Giorgi and Monica Sassatelli, 173-189. New York: Routledge.

Chen, Katherine K. 2012. "Artistic Prosumption: Cocreative Destruction at Burning Man". American Behavioral Scientist 56(4): 570-95. <http://dx.doi.org/10.1177/0002764211429362>

Cova, Bernard, Robert V. Kozinets and Avi Shankar, eds. 2007. Consumer Tribes. Burlington: Elsevier. Csikszentmihalyi, Mihaly. 1990. Flow: The Psychology of Optimal Experience. New York: Harper and Row.

D’Andrea, Anthony. 2007. Global Nomads: Techno and New Age as Transnational Countercultures in Ibiza and Goa. New York: Routledge.

Holt, Fabian. 2015 forthcoming. "New Media, New Festival Worlds: Rethinking Cultural Events and Televisuality through YouTube and the Tomorrowland Music Festival". In Music and the Broadcast Experience, eds. James Deaville and Christina Baade. Oxford: Oxford University Press.

Johansson, Marjana and Maria Laura Toraldo. 2015. “From mosh pit to posh pit': Festival Imagery in the Context of the Boutique Festival". Culture and Organization. Published Online. <http://dx.doi.org/10.1080/14759551.2015.1032287>.

Jones, Steven T. 2011. The Tribes of Burning Man: How an Experimental City in the Desert Is Shaping the New American Counterculture. San Francisco: CCC Publishing.

Lalioti, Vassiliki. 2013. “'Stay in Synch!': Performing Cosmopolitanism in an Athens Festival”. Dancecult: Journal of Electronic Dance Music Culture, 5(2): 131-51. $<$ http://dx.doi.org/10.12801/1947-5403.2013.05.02.07>.

Lawrence, Tim. 2003. Love Saves the Day: A History of American Dance Music Culture, 19701979. Durham: Duke University Press.

McKay, George, ed. 2015. The Pop Festival: History, Music, Media, Culture. New York: Bloomsbury Academic. Nye, Sean and Ronald Hitzler. 2011. "Where is Duisburg? An LP Postscript". Dancecult: Journal of

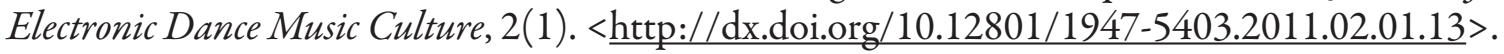

O’Grady, Alice. 2015. "Alternative Playworlds: Psytrance Festivals, Deep Play and Creative Zones of Transcendence". In The Pop Festival: History, Music, Media, Culture, ed. George McKay, 149-164. New York: Bloomsbury Academic.

Pongsakornrungsilp, Siwarit, and Jonathan. E. Schroeder. 2011. "Understanding Value CoCreation in a Co-Consuming Brand Community". Marketing Theory 11(3): 303-324. <http://dx.doi.org/10.1177/1470593111408178>. 
Reynolds, Simon. 1997. "Rave Culture: Living Dream or Living Death?” In The Clubcultures Reader: Readings in Popular Cultural Studies, ed. Steve Redhead, 102-11. Oxford: Blackwell.

Rietveld, Hillegonda. 1998. This is Our House: House Music, Cultural Spaces, and Technologies. Aldershot: Ashgate.

Robinson, Roxy. 2015. "No Spectators! The Art of Participation: From Burning Man to Boutique Festivals in Britain". In The Pop Festival: History, Music, Media, Culture, ed. George McKay, 165-182. New York: Bloomsbury Academic.

Rom, Tom and Pascal Querner. 2011. Goa: 20 Years of Psychedelic Trance. Solothurn/Switzerland: Nachtschatten Verlag.

St John, Graham. 2009. Technomad. Global Raving Countercultures. London: Equinox. -_- 2012. Global Tribe: Technology, Spirituality and Psytrance. Sheffield: Equinox.

_- _ 2013. "Total Solar Eclipse Festivals, Cosmic Pilgrims and Planetary Culture". In Pop Pagans: Pagans and Popular Music, eds. Donna Weston and Andy Bennett, 126-144. Durham: Acumen.

_- _ 2014a. "Goatrance Travellers: Psytrance and its Seasoned Progeny". In The Globalization of Musics in Transit: Musical Migration and Tourism, eds. Simone Krüger and Ruxandra Trandafoiu, 160-182. New York: Routledge.

- - - 2014b. "Begoggled in the Theater of Awe: Electronic Dance Music Culture at Burning Man." In Playa Dust: Collected Stories from Burning Man, ed. Samantha Krukowski, 144-159. London: Black Dog Publishing.

- - - 2014c. "The Logics of Sacrifice at Visionary Arts Festivals". In The Festivalisation of Culture, eds. Andy Bennett, Jodie Taylor and Ian Woodward, 49-68. Aldershot: Ashgate.

Turino, Thomas. 2008. Music as Social Life: The Politics of Participation. Chicago: University of Chicago Press.

Turner, Erik. 2014. "Transformational Festivals: Reflections on Social Movements and Transformational Festivals as Civil Spheres”. PsypressUK (December 8). < http://psypressuk. com/2014/12/08/transformational-festivals-reflections-on-social-movements-andtransformational-festivals-as-civil-spheres-by-eric-turner> (accessed 15 May 2015).

Turner, Victor. 1969. The Ritual Process: Structure and Anti-Structure. Chicago: Aldine.

\section{FILMOGRAPHY}

Cutforth, Dan and Jane Lipsitz. 2014. Under the Electric Sky. DVD. Universal.

DROID i.d. 2013. The Alchemy of Spirit. Part 1. Lisbon, Portugal: Boom Team. <http://www.youtube.com/watch?v=ZTrsenzgJCQ> (accessed 14 May 2015).

Johner, Andrew. 2013. Electronic Awakening. DVD. North Atlantic.

Leung, Jeet Kei. 2010. “Transformational Festivals”. TEDx Vancouver.

$<$ http://tedxtalks.ted.com/video/TEDxVancouver-Jeet-Kei-Leung-Tr> (accessed 15 May 2015).

Leung Jeet-Kei and Akira Chan. 2014. The Bloom Series. Elevate Films, Keyframe Entertainment, Muti Music \& Grounded TV. <http://thebloomseries.com $>$.

Tomorrowland 2011. Official aftermovie. <https://www.youtube.com/watch?v=M7CdTAiaLes $>$ (accessed 14 May 2015). 